\title{
Administrative Courts a Defense Against Populism
}

\author{
Ana Fierro ${ }^{1}$ \\ Centro de Investigación y Docencia Económica (CIDE), México
}

\begin{abstract}
Over the past two decades, populist governments have proliferated in America. These governments are characterized by reducing to mere formalism the procedures of control of the rule and intervene in the judiciary and administrative courts. Modern society worked hard to achieve legal systems based on the rule of law, in order to prevent citizens from being subject to the will of one leader. In our legal systems administrative courts play a fundamental role improving state bodies. This paper explores the use of administrative courts as accountability mechanisms that protect the rule of law. We suggest that administrative courts are powerful procedures for accountability and control against abuse of powers. Finally, we recommend states should broaden access to these mechanisms, given the fact that administrative trails are still very restricted to most of the citizens."
\end{abstract}

Keywords: Accountability, administrative courts, constitution, human rights, rule of law, nullity trial, state liability trial, judicial control, populism.

Over the past two decades, populist governments have proliferated in America. The most problematic case is Venezuela but trends are visible even in Ecuador, Brazil, Nicaragua and Mexico. These governments are characterized by reducing to mere formalism the procedures of control of the rule of law such as: division of powers, accountability mechanisism, transparency of public work. ${ }^{2}$ Populist governments often intervene in the judiciary and administrative courts, show disdain for institutions that gather information and evaluate the performance of government such as government account offices. These agencies, responsible for checks and balance to the executive branch often face attacks to their independance and pressures. As Kyle and Mounk's study of 36 populist governments in the 21 century shows there is $23 \%$ more probality that democratic institutions are damaged, and more than $50 \%$ of populist leaders reform constitutions to weaken executive checks and balances, more than $40 \%$ of populist challenge or disregard laws. ${ }^{3}$ Hence reducing democracy to its

\footnotetext{
${ }^{1}$ Dean of Master Program of Public Policy and Public Administration, Centro de Investigación y Docencia Económica (CIDE). ana.fierro@cide.edu

${ }^{2}$ Cesáreo Rodríguez Aguilera de Prat, La derecha iliberal frente al Estado de derecho, AGENDA_PúBLICA-EL PAIS (Sept. 27, 2019).

${ }^{3}$ Jordan Kyle \& Yascha Monk, The Populist Harm to Democracy AND EMPIRICAL AsSESSMent (2018).
} 
minimum by replacing institutions that protect the rule of law with the mobilization of people that grant unconditional support to a strong lider. ${ }^{4}$

Authors like Vergara ${ }^{5}$ and Mouffe $^{6}$ point out that the disillusion with democracies results form the fact that in modern states a large part of the population is marginalized from public decision-making. Only a minority with economic power succeed in influencing public decisions. While this criticism is attainable it is also true that accountability procedures, such as nulity and state liabilty trails are a powerful weapons for controlling public decisions in the hands of citizens. Modern society worked hard to achieve legal systems based on the rule of law and the promotion of human rights. These legal systems prevent citizens from being subject to the will of one leader. In our legal systems administrative courts play a fundamental role in controlling power and improving the performance of state bodies. These trails are a powerful weapon in the hands of all people. In fact, in the face of populism's advancement, having mechanisms to control the exercise of public powers and the use of public money, such as nullity and state liability trails becomes a powerful citizen's tool against arbitrariness and in favor of the rule of law. If disappointment with democracy comes from the lack of control of majorities over public decisions, access to administrative courts should be promoted as a means in the hands of everyone to bring government into account and control de abuse of power.

This paper explores the use of administrative courts as accountability mechanisms that protect the rule of law. Following Kitrosser, ${ }^{7}$ we understand accountability as the substantive dimension of the rule of law and part of the overall control of power by Congress and the judicial branch. We suggest that administrative courts are powerful procedures for government accountability and control against abuse of powers. We analyse nullity and state liability trails to show their use not only as tools for protecting the rule of law, but also for bringing the authorities to account and ordering measures for their improvement. We attempt to show the challenges these procedures still encounter to ensure access to justice and defence against abuse of power for everyone.

\footnotetext{
4 Vox Populi: Populismo y democracia de Latinoamérica 9-19 (Julio Aibar Gaete ed., 2007).

${ }^{5}$ Camila Vergara, Populism as Plebeian Politics: Inequality, Domination, and Popular Empowerment, 28 Journal OF Political Philosophy 222-46 (2020).

${ }^{6}$ Chantal Mouffe, La "fin du politique" et le défi du populisme de droite, RevuE Du MAUSs 178-194 (2002).

${ }^{7}$ H. KitrosSER, RECLAIMING ACCOUNTABILITY: TRANSPARENCY, EXECUTIVE POWER, AND THE U.S. CONSTITUTION (2018).
} 
In this paper we define accountability as a bilateral procedure between an agency obliged to inform and justify its actions to a court empowered to sanction them. ${ }^{8}$ Agencies are bound by the rule of law, but the legal system must have means to control their compliance. This guarantee is given by the administrative courts that review the legality and constitutionality of government actions making them accountable. Administrative courts serve as an oversight and accountability mechanism for decision-makers, these mechanisms ensure agencies follow appropriate processes and act according to their statutory mandates. They aim to boost public confidence and credibility of their decision-making, facilitate better and more consistent decisions, and reduce the risk of errors. They also promote fairness and justice, are means to prevent corruption, and provide opportunities to address wrongs through redress. ${ }^{9}$ Therefore, administrative courts are important controls of abuses of power. Populist seek to concentrate power by making decisions without due process, or exceeding the statutory limits, nullity and state liability trials can be used to stop them.

Professor Ginsburg points out that in the transition from authoritarian to democratic regimes controls of power shift from being predominantly ideological, and hierarchical, to institutionalized controls by accountability mechanisms. In democracies administrative courts become important accountability mechanisms of control of government actions. Hence administrative courts are often strengthened, as means where individuals denounce irregular actions that depart from the rule of law. This allows for the decentralization of control and empowers citizens to bring claims against government abuses. In this sense, individuals play an essential role in the defense of their rights as well as making agencies accountable for their actions. ${ }^{10}$ Populist government in contrast try to undermine this controls.

Administrative trails are forms of control through red flags activated by the public itself, who denounce decisions that do not adhere to legal or constitutional parameters. The claims brought in front of the court work as an alarm when government decisions are contrary to the rule of law. Moreover, the adversarial nature of trails brings to light elements that the agency would hardly reveal for itself. This information becomes public and may transcends to higher levels, including other branches such as the Legislative or the media. ${ }^{11}$ This achieves an

\footnotetext{
${ }^{8}$ ANA ELENA FIERRo FERRÁEs, Visión GENERAL dE LA RENDICIÓN DE CUENTAS DE AUTORIDADES ELECTAS EN EL ORDENAMIENTO JURÍDICO MEXICANO (2011).

${ }^{9}$ Lorne Sossine \& Hoffman Steven, The Elusive Search For Accountability: Evaluating Adjudicative Tribunals, 28 WINDSOR YEARBOOK OF ACCESS TO JusticE (2) 343-60, 2010.

${ }^{10}$ Tom Ginsburg, Administrative Law and the Judicial Control of Agents in Authoritarian Regimes, in RuLE BY LAw: THE Politics of Courts in Authoritarian Regimes 58-72 (Tom Ginsburg \& Tamir Moustafa eds, 2008).

${ }^{11} \mathrm{Id}$. at $58-72$.
} 
accountability procedure that does not depend on permanent ad hoc bodies, or general oversights. Also Nohlen ${ }^{12}$ considers there is a close relationship between democracy, accountability and the Constitution, on the one hand accountability is an element of democracy but, at the same time, the effectiveness of the means of control of constitutionality and the rule of law safeguards the supreme law of the land and the principle of democracy in it. Therefore, this accountability mechanism are important controls against the advancement of populist action that seek to weaken the rule of law.

Even though administrative trails are important defenses against abuses of power they are not always accessible to everybody. In some cases, the general public are not familiar with these procedures, in others legal counsel is expensive, the formalisms of the trail discourage people to bring claims. In this sense, especially in Latin America administrative courts are frequently use by the elites and less by vulnerable groups in society. States should broaden access to these mechanisms of accountability, by providing public defenders and making procedures more flexible. It is also important to educate people in their rights, and the ways the legal system provides them to defend them, as well as the importance of making government accountable for their decisions. Against the advancement of populist governments that threaten the rule of law people should have effective means to stop them, administrative trails are powerful arms for this purpose.

\section{REFERENCE LIST}

ANA ELENA FIERRO FERRÁES, VISIÓN GENERAL DE LA RENDICIÓN DE CUENTAS DE AUTORIDADES ELECTAS EN EL ORDENAMIENTO JURÍDICO MEXICANO (2011).

Camila Vergara, Populism as Plebeian Politics: Inequality, Domination, and Popular Empowerment, 28 Journal OF POLITICAL PhILOSOPHY 222-46 (2020). doi:10.1111/jopp.12203

Cesáreo Rodríguez Aguilera de Prat, La derecha iliberal frente al Estado de derecho, AGENDA_PÚBLICA-EL PAIS (Sept. 27, 2019), http://agendapublica.elpais.com/la-derechailiberal-frente-al-estado-de-derecho/

Chantal Mouffe, La "fin du politique" et le défi du populisme de droite, REVUE DU MAUSS 178-194 (2002).

H. KITROSSER, RECLAIMING ACCOUNTABILITY: TRANSPARENCY, EXECUTIVE POWER, AND THE U.S. CONSTITUTION (2018).

HÉCTOR FIX-FIERRO \& DiETER NOHLEN, LOS TRIBUNALES CONSTITUCIONALES EN LA CONSOLIDACIÓN DEMOCRÁtiCA. SuPREMA CORTE DE JuSTICIA DE LA NACIÓN (2008).

\footnotetext{
${ }^{12}$ Héctor FiX-Fierro \& Dieter Nohlen, Los tribunales CONSTITUCIONALES EN LA CONSOLIDACión DEMOCRÁTICA. SuPREMA CORTE DE JUSTICIA DE LA NACIÓN 43-103 (2008).
} 
JoRdAN Kyle \& YASCHA MONK, THE POPUlist HARM TO DEMOCRACY AND EMPIRICAL ASSESSMENT (2018), https://institute.global/insight/renewing-centre/populist-harmdemocracy

Lorne Sossine \& Hoffman Steven, The Elusive Search For Accountability: Evaluating Adjudicative Tribunals, 28 WiNDSOR YEARBOOK OF ACCESS TO JUSTICE (2) 343-60, 2010, http://www.uwindsor.ca/law/ljacobs/sites/uwindsor.ca.law.ljacobs/files/windsor_yearbook_a dmin_law_special_issue_2010_final.pdf

Tom Ginsburg, Administrative Law and the Judicial Control of Agents in Authoritarian Regimes, in RUle By LAW: THE POLITICS OF COURTS IN AUTHORITARIAN REGIMES 58-72 (Tom Ginsburg \& Tamir Moustafa eds, 2008). doi:10.1017/CBO9780511814822.003

Vox Populi: Populismo y DEMOCRACIA DE LATINOAMÉRICA 9-19 (Julio Aibar Gaete ed., 2007). 